6 Grantham-McGregor S. Field studies in early nutrition and later achievement. In: Dobbing J, ed. Early nutrition and later achievement. London: Academic Press, 1987:128-74.

7 Richardson SA. The relation of severe malnutrition in infancy to the intelligence of school children with differing life histories. Pediatr Res 1976;10:57-61.

8 Smart JL. Malnutrition, learning and behavior: 25 years on from the MIT symposium. Proc Nutr Soc 1993;52:189-99.

Katz HG. The influence of undernutrition on learning performance in rodents. Nutr Abs Rev 1980;50:767-83.

10 Smart JL. Early life malnutrition and later learning ability-critical analysis. In: Oliverio A, ed. Genetics, environment and intelligence. Amsterdam: Elsevier, 1977:215-35.

11 Lucas A, Gore SM, Cole TJ, Bamford MF, Dossetor JF, Barr I, et al. Multicentre trial on feeding low birthweight infants: effects of diet on early growth. Arch Dis Child 1984;59:722-30.

12 Lucas A, Morley R, Cole TJ, Gore SM, Lucas PJ, Crowle P, et al. Early diet in preterm babies and developmental status at 18 months. Lance 1990;335:1477-81.

13 Lucas A. Enteral nutrition. In: Tsang R, Lucas A, Uauy R, Zlotkin S, eds. Nutritional needs of the preterm infant. Pawling, United States: Caduceus Medical Publishers, 1993:209-23.

14 McCall RB. The development of intellectual functioning in infancy and the prediction of later IQ. In: Osofsky JD ed. The handbook of infant development. New York: Wiley, 1979:707-41.

15 Cronbach LJ. Essentials of psychological testing. New York: Harper Collins, 1990:284.

16 Morley R, Cole TJ, Powell R, Lucas A. Mother's choice to provide breast milk and developmental outcome. Arch Dis Child 1988;63:1382-5.
17 Psychological Corporation. Wechsler intelligence scale for children, Anglicised. Rev ed. Sidcup: Psychological Corporation, 1974.

18 McNemar Q. Correction to a correction. J Consult Clin Psychol 1974;42:145-6.

19 Lucas A, Morley R, Cole TJ, Lister G, Leeson-Payne C. Breast milk and subsequent intelligence quotient in children born preterm. Lancet 1992:339:261-4.

20 Grantham-McGregor SM, Walker SP, Chang SM, Powell CA. Effects of early childhood supplementation with and without stimulation on later development in stunted Jamaican children. Am J Clin Nutr 1997;66:247 53.

21 Lucas A, Morley R, Cole TJ, Bamford MF, Boon A, Crowle P, et al. Early diet in preterm babies and developmental status in infancy. Arch Dis Child 1989;11:1570-8.

22 Smart JL. Undernutrition, learning and memory: review of experimental studies. In: Taylor TG, Jenkins NK, eds. Proceedings of XIII international congress of nutrition. London: John Libbey, 1986:74-8.

23 Fitzhardinge PM, Steven EM. The small-for-date infant. II. Neurologica and intellectual sequelae. Pediatrics 1972;50:50-7.

24 Kolb B, Whishaw IQ. Development and recovery. In: Fundamentals of neuropsychology. 3rd ed. New York: Freeman, 1990:679-711.

25 Cooke RWI, Lucas A, Yudkin PLN, Pryse-Davies J. Head circumference as an index of brain weight in the fetus and newborn. Early Hum Der 1977;1/2:145-9

26 Lucas A. Programming by early nutrition in man. In: Barker D, ed. The childhood environment and adult disease. Chichester: Wiley, 1991:38-55. (CIBA Foundation Symposium 156.)

(Accepted 27 August 1998,

\title{
Randomised controlled trial of novel, simple, and well supervised weight reducing diets in outpatients
}

\author{
Carolyn D Summerbell, Carolyn Watts, Julian P T Higgins, John S Garrow
}

\begin{abstract}
Objectives To investigate the contribution of novelty and simplicity to compliance with a low energy diet among obese outpatients.

Design Three arm randomised trial for 16 weeks. Setting NHS hospital obesity clinic.

Subjects 45 patients aged over 17 years with a body mass index $>27$ who were not diabetic, pregnant, or lactating.

Interventions Conventional 3.4 MJ diet (control), isoenergetic novel diet of milk only, or milk plus one designated food daily. Follow up visit every 4 weeks.

Main outcome measure Weight loss.

Results Mean weight loss (kg) after 16 weeks on control, milk only, and milk plus diets was 1.7 (95\% confidence interval -0.3 to 3.7$), 9.4$ (5.9 to 12.9 ), and 7.0 (2.7 to 11.3 ) respectively. Weight loss on the novel diets was significantly greater than on the control diet. Conclusions Dietary treatment can achieve as much weight loss in obese outpatients over 16 weeks as has been reported for the most successful drug treatment, but compliance with the prescribed diet is poor unless the diet is novel and simple.
\end{abstract}

\section{Introduction}

Outpatient dietary weight reduction for obesity is unsatisfactory, ${ }^{12}$ but inpatient dieting is extremely effective. ${ }^{3}$ Obese patients lose weight more rapidly as inpatients than as outpatients when nominally on the same diet, which can be explained only by compliance. Some of the most impressive weight losses achieved by outpatient dietary treatment have been in the placebo control arm of drug trials. ${ }^{56}$ The ambience of a controlled drug trial seems to be conducive to high compliance with dietary treatment and hence good weight loss. The patient is reviewed regularly and believes that the treatment is something novel which may succeed.

This study was designed to test the hypothesis that prescription of simple, novel diets would result in higher levels of compliance and weight loss in an outpatient setting over 16 weeks. Patients were randomised to one of three diets, each of which was designed to produce an initial energy deficit of 4-7 MJ a day.

\section{Subjects and methods}

\section{Recruitment and randomisation}

All new patients aged over 17 attending an obesity outpatient clinic at St Bartholomew's Hospital between 1 November 1993 and 13 May 1994 were eligible if their body mass index (weight $(\mathrm{kg}) /\left(\right.$ height $\left.(\mathrm{m})^{2}\right)$ was $>27$ and they were not diabetic, pregnant, or lactating. Eligibility was assessed by JSG, who was blind to the subsequent allocation of treatment.

All patients had their weight and height measured by the clinic nurse and were given appointments to return to the clinic every four weeks for 16 weeks. At the first visit JSG took a medical history and did a physical examination. CDS then performed the initial randomisation, gave dietary advice, and explained how to record dietary intake. Randomisation was achieved by using blocks of six sealed, opaque envelopes (equal allocation) from which sequential patients chose one. Exact blocking was disturbed because a partly used block of envelopes was mislaid. At subsequent visits

\author{
Rank Department \\ of Human \\ Nutrition, \\ St Bartholomew's \\ Hospital Medical \\ College, London \\ EC1M 6BQ \\ Carolyn D \\ Summerbell, \\ lecturer in nutrition \\ Carolyn Watts, \\ research dietitian \\ John S Garrow, \\ professor of human \\ nutrition \\ Department of \\ Epidemiology and \\ Public Health, \\ Institute of Child \\ Health, London \\ WC1N 1EH \\ Julian P T Higgins, \\ research fellow in \\ medical statistics \\ Correspondence to: \\ Dr Summerbell, \\ School of Health, \\ University of \\ Teesside, \\ Middlesbrough \\ TS1 3BA \\ carolyn.summerbell@ \\ tees.ac.uk
}

BMJ 1998;317:1487-9 


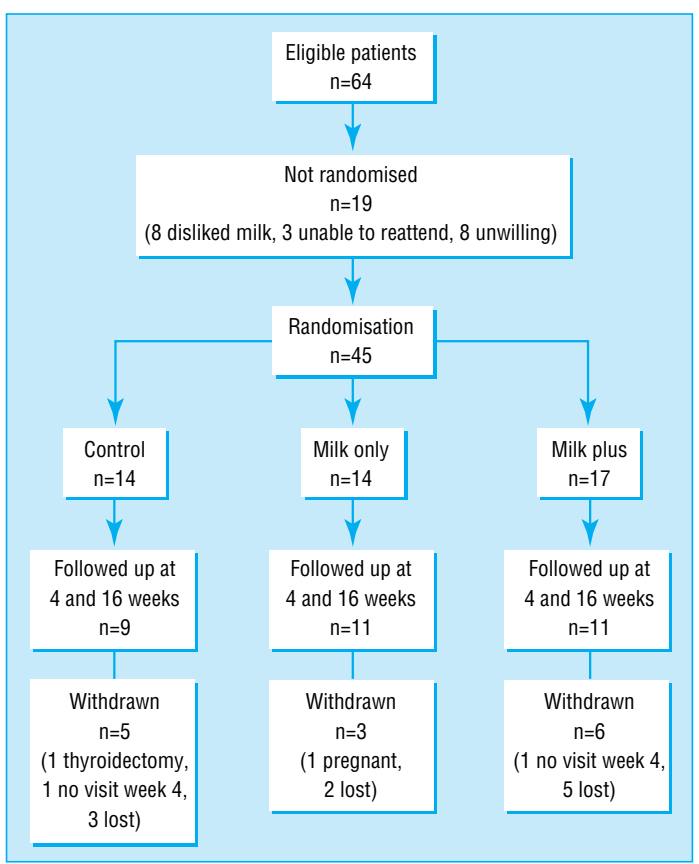

Randomisation and follow up of patients in trial

patients were seen by JSG, and CDS and CW reviewed the food records and provided advice about the diet. CW administered psychological rating scales and a questionnaire (results not reported).

\section{Interventions}

Energy free fluid intake was unrestricted in all diets.

Control-A conventional balanced diet composed of a variety of normal foods designed to supply about $3.4 \mathrm{MJ}$ daily with at least $36 \mathrm{~g}$ protein.

Milk only-A variable combination of full cream or semi-skimmed milk and unsweetened yoghurt to provide the energy equivalent of the control diet. This diet was novel and simple but very restrictive.

Milk plus-This was the milk only diet with the addition of an unlimited amount of a single food selected by the patient on each day of the week. Of these seven extra foods, three were a fruit or vegetable, two were a high protein food, and two were a "favourite" food. The seven foods were repeated on the same day of successive weeks. It was intended to give the patient greater power to decide the nature of the diet without greatly affecting its nutritional characteristics. On average, this diet supplied 5.6 MJ.

\section{Statistical analysis}

We performed an intention to treat analysis (using last available weight) and an analysis of patients attending at both week 4 and 16. Confidence intervals are based on $t$ tests, assuming unequal variances for comparisons. Mann-Whitney tests, performed because positive skew was introduced in the intention to treat analysis, did not alter significance; means are presented for simplicity.

\section{Results}

Sixty four patients met the criteria for the trial (figure). After the protocol was explained 19 patients declined to be randomised, leaving 45 patients. Baseline characteristics were similar in the three groups (table1) and a similar proportion in each group completed the trial. The table shows the weight loss from baseline at four and 16 weeks and table 2 shows the mean differences between the groups.

\section{Discussion}

This trial was a realistic test of what can be achieved by dietary treatment alone for obese patients in NHS facilities. The patients were typical of those referred by general practitioners to a hospital obesity clinic $^{7}$ : they travelled to the clinic at their own expense, neither paid nor received money, and bought the food they ate at normal retail outlets. No drug or surgical treatment was offered and no exercise or behavioural therapy programmes were provided.

Within the limitations of a trial lasting only 16 weeks our results support the received wisdom that

Table 1 Mean (SD) baseline characteristics and weight loss of patients who were randomised to control, milk only, and milk plus diets. Results shown for all randomised patients (intention to treat analysis) and for those completing trial

\begin{tabular}{|c|c|c|c|c|c|c|}
\hline \multirow[b]{2}{*}{ Group } & \multicolumn{2}{|c|}{ Control } & \multicolumn{2}{|c|}{ Milk only } & \multicolumn{2}{|c|}{ Milk plus } \\
\hline & $\begin{array}{c}\text { Randomised } \\
(\mathrm{n}=14)\end{array}$ & $\begin{array}{c}\text { Completed } \\
(\mathrm{n}=9)\end{array}$ & $\begin{array}{c}\text { Randomised } \\
(\mathrm{n}=14)\end{array}$ & $\begin{array}{c}\text { Completed } \\
(n=11)\end{array}$ & $\begin{array}{c}\text { Randomised } \\
(\mathrm{n}=17)\end{array}$ & $\begin{array}{c}\text { Completed } \\
(\mathrm{n}=11)\end{array}$ \\
\hline Sex (M/F) & $3 / 11$ & $1 / 8$ & $3 / 11$ & $2 / 9$ & $4 / 13$ & $3 / 8$ \\
\hline Age (years) & $39.5(13.9)$ & $38.1(15.0)$ & $45.2(14.8)$ & $46.0(14.3)$ & $41.1(11.5)$ & $41.4(13.4)$ \\
\hline Weight (kg) & $122(38)$ & $118(33)$ & $116(17)$ & $114(17)$ & $129(26)$ & $127(28)$ \\
\hline Body mass index & $43.0(9.2)$ & $41.4(9.0)$ & $43.1(7.7)$ & $42.6(8.1)$ & $46.6(9.1)$ & $44.9(9.3)$ \\
\hline \multicolumn{7}{|c|}{ Weight loss at 4 weeks $(\mathrm{kg})$} \\
\hline Mean (SD) & $0.9(2.7)$ & $1.4(3.4)$ & $6.4(3.5)$ & $7.4(2.4)$ & $2.8(3.3)$ & $4.3(3.2)$ \\
\hline Range & -3.7 to 7.9 & -3.7 to 7.9 & 0.0 to 11.5 & 3.3 to 11.5 & -0.7 to 10.5 & -0.7 to 10.5 \\
\hline \multicolumn{7}{|c|}{ Weight loss at 16 weeks $(\mathrm{kg})$} \\
\hline Mean (SD) & $1.7(3.5)$ & $2.6(4.1)$ & $9.4(6.1)$ & $11.2(5.2)$ & $7.0(8.4)$ & $8.2(7.4)$ \\
\hline Range & -0.9 to 10.7 & -0.9 to 10.7 & -0.4 to 18.6 & -0.4 to 18.6 & 0.0 to 25.6 & -0.7 to 24.5 \\
\hline
\end{tabular}

Table 2 Mean difference (95\% confidence interval) in weight loss between patients randomised to control, milk only, and milk plus diets. Results shown for all randomised patients (intention to treat analysis) and for those completing trial

\begin{tabular}{|c|c|c|c|c|c|c|}
\hline & \multicolumn{2}{|c|}{ Milk only $v$ control } & \multicolumn{2}{|c|}{ Milk plus v milk only } & \multicolumn{2}{|c|}{ Milk plus $v$ control } \\
\hline & Randomised & Completed & Randomised & Completed & Randomised & Completed \\
\hline 4 weeks & 5.5 (3.1 to 7.9$)$ & $6.1(3.2$ to 8.9$)$ & $-3.6(-6.0$ to -1.1$)$ & $-3.1(-5.6$ to -0.6$)$ & $1.9(-0.3$ to 4.1$)$ & $2.9(-0.2$ to 6.1$)$ \\
\hline 16 weeks & 7.7 (3.8 to 11.6$)$ & $8.6(4.2$ to 12.9$)$ & $-2.4(-7.7$ to 2.9$)$ & -3.0 (-8.7 to 2.7$)$ & $5.3(0.7$ to 9.9$)$ & $5.6(0.0$ to 11.1$)$ \\
\hline
\end{tabular}


Key messages

- Energy reducing diets often work poorly in obese outpatients, although they are effective for inpatients

- In this study patients put on a milk only diet had significant weight loss

- Weight loss was comparable with that achieved by drugs

- Patients are more likely to respond to a simple diet which they have not tried before than to advice on conventional diets

"diets do not work," at least as far as the conventional balanced reducing diet is concerned. The milk only diet was simple and patients had not tried it before. Patients completing the trial in this group achieved the highest overall mean weight loss (11.2 kg in 16 weeks), which is greater than the mean weight loss in one year in trials of dexfenfluramine, ${ }^{8}$ sibutramine, ${ }^{9}$ or orlistat. $^{10}{ }^{11}$ Patients consuming only milk might be expected to become deficient in some vitamins and iron, but this was not found in another longer trial ${ }^{4}$; constipation was the only serious side effect reported.

We expected that patients on the milk plus diet would have a greater weight loss than those on the milk only diet as it was still simple but much less boring and patients were more likely to comply with it. The milk plus diet is also theoretically superior as it provides a greater variety of nutrients and an energy deficit of about $4 \mathrm{MJ} /$ day instead of a $7 \mathrm{MJ} /$ day deficit on milk only, which would cause an excessive loss of lean tissue. ${ }^{4}$ Analysis of compliance (not reported) showed that it was similar for the two milk diets but much lower for the conventional diet.
We are not advocating milk only as a general long term reducing diet for obese outpatients, because in the long term it will cease to be novel and compliance will fall. Probably the best strategy is to rotate diets, just as rotation of anorectic drugs achieves greater long term weight loss than continuous use of a single drug. $^{12}$

Contributors: CDS, CW, and JSG designed and carried out the study.JPTH and CDS did the statistical analysis. JSG drafted the paper, which was revised and approved by all authors. CDS is the study guarantor.

Funding: None.

Conflict of interest: None

1 Scottish Intercollegiate Guidelines Network. Obesity in Scotland. Edinburgh: SIGN, Royal College of Physicians, 1996.

2 Glenny A-M, O'Meara S, Melville A, Sheldon TA, Wilson C. The treatment and prevention of obesity: a systematic review of the literature. Int J Obes 1997;21:715-37.

3 Bortz WM. A 500 pound weight loss. Am J Med 1969;47:325-31.

4 Garrow JS, Webster JD, Pearson M, Pacy PJ, Harpin G. Inpatientoutpatient randomised comparison of Cambridge diet versus milk diet in 17 women over 24 weeks. Int J Obes 1989;13:521-9.

5 Wing RR, Jeffery RW. Outpatient treatments of obesity: a comparison of methodology and clinical results. Int J Obes 1979;3:261-79.

6 Bray GA. Coherent preventive and management strategies for obesity. In: Chadwick DJ, Cardew G, eds. The origins and consequences of obesity. CIBA symposium 201. Chichester: Wiley, 1996.

7 Garrow JS. Obesity and related diseases. London: Churchill Livingstone, 1988

8 Guy-Grand B, Apfelbaum M, Crepaldi G, Gries A, Lefebvre P, Turner P International trial of long-term dexfenfluramine in obesity. Lancel 1989;ii:1142-5.

9 Lean MEJ. Sibutramine-a review of clinical efficacy. Int J Obes 1997;21(suppl 1):S30-6

10 James WPT, Avenell A, Broom J, Whitehead J. A one-year trial to assess the value of orlistat in the management of obesity. Int $J$ Obes 1997;21(suppl 3):S24-30.

11 Sjostrom L, Rissanen A, Andersen T, Boldrin M, Golay A, Koppeschaa HPF, et al. Randomised placebo-controlled trial or orlistat for weight loss and prevention of weight regain in obese patients. Lancet 1998;352: $167-73$

12 Weintraub M. Long term weight control study: conclusions. Clin Pharmacol Ther 1992;51:642-6.

(Accepted 27 August 1998)
On instruction from the Minister of Health, the Department of Health in England convened a task force on the effectiveness of treatment services for drug misusers, and widely distributed its recommendations in 1996. ${ }^{1}$ Methadone constituted $96 \%$ of all opiate prescriptions dispensed to drug misusers. ${ }^{23}$ The task force specifically recommended that $(a)$ methadone tablets should no longer be prescribed for the treatment of drug misuse; $(b)$ daily dispensing should be used to prevent diversion of drugs; and $(c)$ the optimal dosage for methadone maintenance treatment was probably between $50 \mathrm{mg}$ and $100 \mathrm{~g}$ daily. ${ }^{1}$

Much of the drug problem of England and Wales is concentrated in London, ${ }^{45}$ with $23 \%$ of all methadone prescriptions in the area being from the Thames regions. ${ }^{3}$ We report the extent to which changes in line with the three recommendations of the task force occurred in the Thames regions between 1995 and 1997.

\section{Methods and results}

Data were collected nationally on prescriptions dispensed to drug misusers by community pharmacists in $1995^{23}$ and for south east England again in 1997 (first mailshot only) - that is, one year before and one year after the publication of the task force's recommendations. One in four community pharmacies was randomly selected for the 1995 national
National Addiction Centre, Institute of Psychiatry and the Maudsley, London SE5 8AF John Strang, director Janie Sheridan, honorary lecturer

Correspondence to: Professor Strang j.strang@iop.bpmf. ac.uk

BMJ 1998;317:1489-90 